\title{
On the appearance of islet associated autoimmunity in offspring of diabetic mothers: a prospective study from birth
}

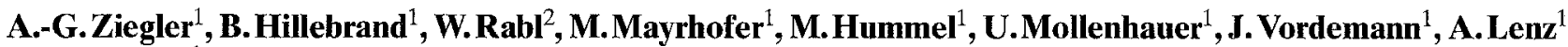 \\ and E.Standl ${ }^{1}$ \\ ${ }^{1}$ Diabetes Research Institute and Schwabing City Hospital, Munich, Germany \\ ${ }^{2}$ Children's Hospital, Technical University, Munich, Germany
}

\begin{abstract}
Summary. For the first time the incidence of insulin autoantibodies and islet cell antibodies were evaluated in a prospective study from birth. Consecutive neonates (168) from mothers with Type 1 (insulin-dependent) diabetes mellitus $(n=113)$ and gestational diabetes $(n=55)$ were included at birth. To date, follow-up sera were obtained from 90 of 168 mother-child-pairs 9 months postpartum and from 39 of 168,2 years postpartum. At birth, there was a strong correlation between the presence of antibodies in the cord blood of neonates and in maternal circulation [Type 1 diabetic mothers: $20 \%$ islet cell antibodies $\geq 20 \mathrm{JDF}-\mathrm{U}$ (detection threshold of our islet cell antibody assay), $74 \%$ insulin antibodies $>49 \mathrm{nU} / \mathrm{ml}$ (upper limit of normal range in sera of healthy control subjects aged 0.5 to 46 years); neonates: $21 \%$ islet cell antibodies $\geq 20 \mathrm{JDF}-\mathrm{U}, 76 \%$ insulin antibodies $>49 \mathrm{nU} / \mathrm{ml}$; gestational diabetic mothers: $11 \%$ islet cell antibodies $\geq 20 \mathrm{JDF}-\mathrm{U}, 18 \%$ insulin antibodies $>$ $49 \mathrm{nU} / \mathrm{ml}$; neonates: $13 \%$ islet cell antibodies $\geq 20 \mathrm{JDF}-\mathrm{U}$, $55 \%$ insulin antibodies $>49 \mathrm{nU} / \mathrm{ml}$. This supports transplacental passage of insulin antibodies and islet cell anti-
\end{abstract}

bodies from diabetic mothers to their offspring. During follow-up, the majority of children lost antibody-positivity after birth. A few offspring, however, exhibited or developed antibodies consistently, whereby insulin autoantibodies preceded islet cell antibodies in each case (antibodypositivity: 9 months: $0 \%$ islet cell antibody positive, $3.3 \%$ insulin autoantibody positive; 2 years: $2.6 \%$ islet cell antibody positive, $7.7 \%$ insulin autoantibody positive). Persisting antibody-positivity in follow-up samples of offspring of diabetic mothers was significantly correlated with older maternal age at delivery (median 38 vs 28 years, $p<0.001$ ). It is concluded that antibodies are common in cord blood of neonates of mothers with Type 1 and gestational diabetes, but they normally disappear after birth. In several children, however, islet cell autoimmunity is detected at very young age.

Key words: Islet cell antibodies, insulin autoantibodies, autoimmunity, mother-offspring-study.
The destruction of pancreatic beta cells in patients with Type 1 (insulin-dependent) diabetes mellitus is autoimmune in nature, but the initiating event and particularly the time when the diabetogenic trigger occurs in life, is not known [1]. Approximately 1 of 20 first degree relatives of patients with Type 1 diabetes will develop the disease and approximately $30-50 \%$ of identical twins are concordant for the disease. Little progress has been made in identifying specific environmental exposure that could provoke clinical manifestation of the genetic predisposition in one patient or prevent it in the other. Based on studies of the risk of Type 1 diabetes developing in the offspring of a parent with Type 1 diabetes, Warram and co-workers [2] have described a lower risk of Type 1 diabetes in children of mothers with Type 1 diabetes than of fathers with Type 1 diabetes and similar findings have been reported by investigators in Germany [3]. There was no evidence that the lower risk can be attributed to selective loss of the susceptible phenotype in perinatal deaths or spontaneous abortion [4], but the factors responsible for that lower risk in the offspring of mothers with Type 1 diabetes remain unknown.

Islet cell antibodies (ICA) and insulin autoantibodies (IAA) appear prior to the development of overt Type 1 diabetes [5-10]. For purposes of studying the respective roles of immunological factors in correlation with clinical variables regarding risk or protection to diabetes, we have begun, for the first time, a prospective study of ICA and IAA in 168 offspring of diabetic mothers ( $n=113$ with Type 1 diabetes and $n=55$ with gestational diabetes) from birth. 


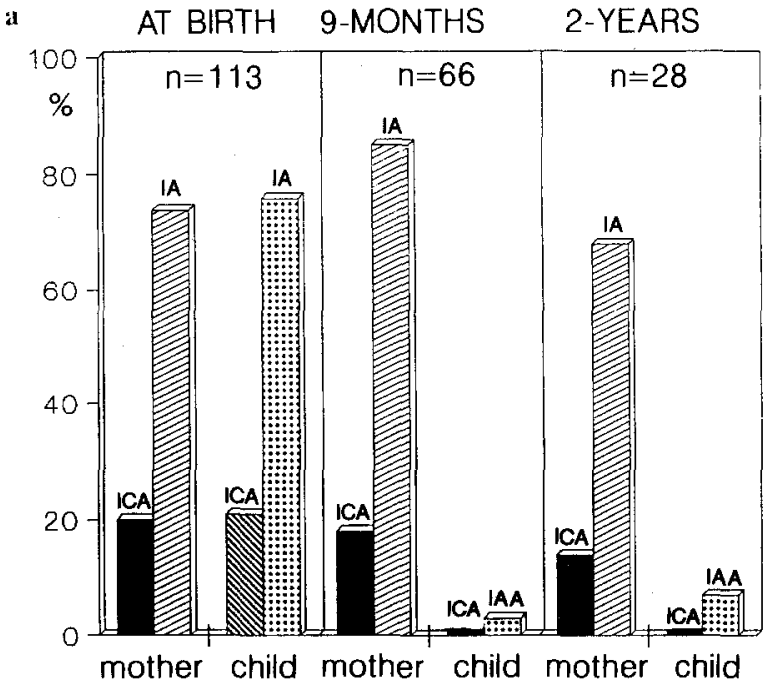

Fig. 1a,b. a Positivity (percent) of islet cell antibodies (ICA $\geq 20 \mathrm{JDF}-\mathrm{U}$ ) and insulin [auto]-antibodies (I[A]A $>49 \mathrm{nU} /$ ml) in Type 1 diabetic mothers and their offspring at birth (left panel), 9 months postpartum (middle panel), and 2 years postpar-

\section{Patients and methods}

\section{Pregnancy and birth}

From July 1989, ICA and I[A]A were determined in 168 consecutive diabetic mothers and in the cord blood of their neonates at birth (113 mothers with Type 1; 55 with gestational diabetes [GDM]). All the pregnant patients were attending the outpatient unit of the Third Medical Department of the Schwabing City Hospital (Munich, FRG) and blood samples for $\mathrm{HbA}_{1}$ were taken at each visit throughout pregnancy. The type of diabetes was classified according to White: 29 White class A (GDM treated with diet); 26 White class BG (GDM-BG = treated with insulin); 29 White class B (diabetes duration $<10$ years or age of onset $>20$ years); 27 White class $\mathrm{C}$ (diabetes duration $>10$ years or age of onset $<20$ years); 38 White class D (non-proliferative retinopathy); 19 White class FR (proliferative retinopathy and/or nephropathy).

At delivery, mean age of diabetic mothers was $28 \pm 4$ (SD) years for Type 1,31 \pm 5 years for GDM-A, and $31 \pm 5$ years for GDM-BG, respectively; mean diabetes duration of Type 1 diabetic mothers was $12 \pm 7$ (SD) years. All insulin-treated mothers were treated with human insulin during pregnancy. Mean individual $\mathrm{HbA}_{1}$ levels throughout pregnancy ranged from $5.2 \%$ to $8.4 \%$ (median $6.6 \%$, mean $\pm \mathrm{SD}: 6.7 \pm 0.8 \%$ ) (normal range: less than $8 \%$ ). Mean gestation duration was $39 \pm 3$ (SD) weeks (range 24-42 weeks, median 39.5 weeks). Mean neonatal weight at birth was $3414 \pm 642$ (SD) g (range $2077-5100 \mathrm{~g}$, median $3460 \mathrm{~g}$ ).

In addition, 17 cord blood samples from neonates of normal healthy parents were used as control samples for the determination of ICA and IAA.

\section{Follow-up}

Follow-up samples for IAA and ICA were obtained from all motherchild pairs, as soon as their children had reached 9 months and 2 years of age, respectively, except for five families who chose not to participate in the follow-up study. To date, of all 168 mother-child pairs studied at birth, 90 diabetic mothers and their offspring were followed-up for 9 months postpartum (66 with Type 1, 12 with GDM-A, and 12 with GDM-BG) and 39 were followed-up for 2 years postpartum (28 with Type 1, 6 with GDM-A, 5 with GDM$B G)$. On follow-up, all mothers were interviewed regarding family history of Type 1 and Type 2 diabetes and breast feeding.

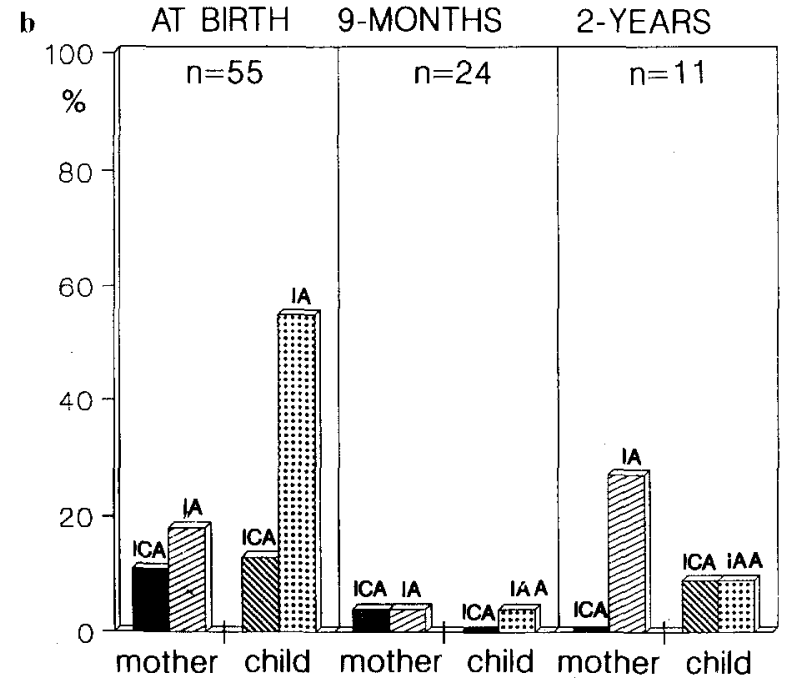

tum (right panel). b Positivity of ICA ( $\geq 20 \mathrm{JDF}-\mathrm{U}$ ) and I[A]A $(>49 \mathrm{nU} / \mathrm{ml})$ in gestational diabetic mothers (including GDM-A and GDM-BG) and their offspring at birth (left panel), 9 months postpartum (middle panel), and 2 years postpartum (right panel)

In addition, 20 samples from non-diabetic children less than age 2 years who were hospitalized at the Children's Department (with no family history of Type 1 diabetes) were used as control samples for the determination of ICA and IAA.

\section{Siblings of "neonates"}

At the 2-year follow-up, all existing siblings ( $n=18$ ), who were born before 1989 , i. e. before our mother-offspring study began, were also investigated for ICA and IAA.

\section{Methods}

Competitive insulin autoantibody assay (IAA). Insulin antibodies were named IA in insulin-treated patients, because these antibodies might have been induced through exogenous insulin therapy; they were named IAA (insulin autoantibodies) in mothers and offspring who had not received any insulin injections.

Serum was tested for IA and IAA using a competitive fluid phase radiobinding assay $[9,11]$. Results are expressed in $\mathrm{nU} / \mathrm{ml}$ of insulin precipitated. Negative IAA levels are computational products where the counts with cold displacement are slightly greater than counts in the absence of unlabelled insulin. The range of IAA values in 103 normal control subjects (mean age $23 \pm 6$ [SD] years) with no family history of diabetes was $-21 \mathrm{nU} / \mathrm{ml}$ to $37 \mathrm{nU} / \mathrm{ml}$ (mean \pm SD: $5 \pm 11 \mathrm{nU} / \mathrm{ml}$ ) and a cutoff of $49 \mathrm{nU} / \mathrm{ml}$ ( 4 SD above normal mean) was utilized as the upper limit of "normal" [12]. For the IDW International Workshop comparing IAA-assays, our assay gave an average control mean delta \% binding of $0.06(\hat{=} 6 \mathrm{nU} / \mathrm{ml})$ and an SD of 0.11 ( $\triangleq 11 \mathrm{nU} / \mathrm{ml})$ [4 SD cutoff: $0.50(\triangleq 50 \mathrm{nU} / \mathrm{ml})$ ].

Islet cell antibody assay (ICA). Sera were screened for ICA on sections of blood group O cryofixed human pancreas utilizing peroxidase conjugated protein $\mathrm{A}[12,13]$. The detection threshold of our ICA assay is $20 \mathrm{JDF}-U$ (Juvenile Diabetes Foundation units; endpoint titre of 1:8 of the ICA standard currently being assessed by the Immunology and Diabetes Workshop).

Insulin assay. Insulin levels in cord blood of neonates were determined by a double antibody radioassay [14]. 

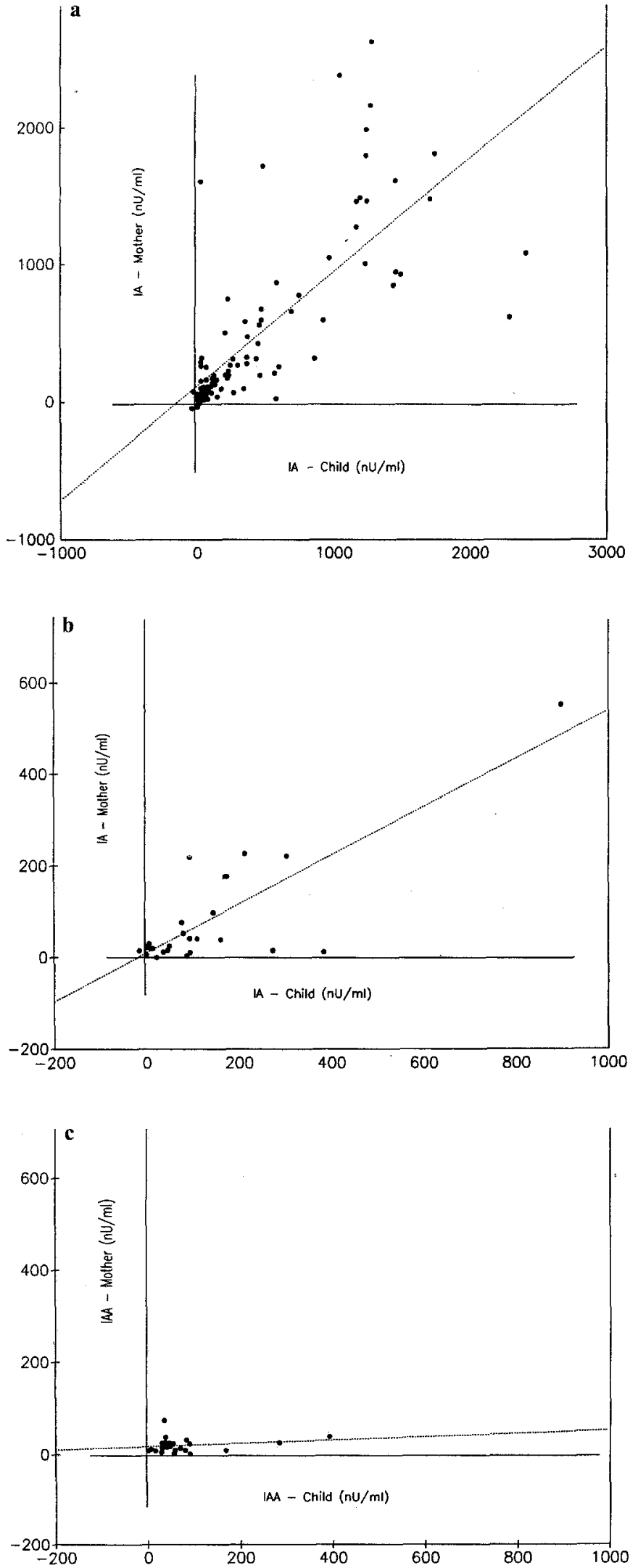

Fig. 2 a-c. a Correlation of insulin-antibody (IA) titre $(\mathrm{nU} / \mathrm{ml})$ in Type 1 diabetic mothers (y-axis) and their offspring ( $\mathrm{x}$-axis) at birth $(r=0.75, p<0.0001)$. b Correlation of IA-titre $(\mathrm{nU} / \mathrm{ml})$ in gestational diabetic mothers (White class GDM-BG) and their offspring at birth $(r=0.81, p<0.0001)$. c Correlation of insulin-autoantibody (IAA) titre $(\mathrm{nU} / \mathrm{ml})$ in gestational diabetic mothers (White class GDM-A) and their offspring at birth $(r=0.21, p<0.05)$

\section{Statistical analysis}

Results were expressed as mean \pm SD (SEM) or median values. Statistical analyses utilized the two-tailed Student's $t$-test, Wilcoxon rank test, and Fisher's exact test. The correlation between IAA levels in the sera of diabetic mothers and their offspring was calculated with linear regression analysis.

\section{Results}

\section{At birth}

Diabetic mothers and their neonates: Of Type 1 diabetic mothers, $20 \%$ (23 of 113) were found to be ICA positive $(\geq 20 \mathrm{JDF}-\mathrm{U})$ and $74 \%$ (84 of 113) IA positive ( $>49 \mathrm{nU} / \mathrm{ml}$ ). Similarly, $21 \%$ ( 24 of 113 ) of their neonates were found to be ICA positive ( $\geq 20 \mathrm{JDF}-\mathrm{U}$ ) and $76 \%$ (86 of 113) had IA above $49 \mathrm{nU} / \mathrm{ml}$ (Fig. 1 a, left panel). ICA were mainly observed in those infants whose mothers were ICA positive (18 mother $[\mathrm{m}]+/$ neonate $[\mathrm{n}]+$, $5 \mathrm{~m}+/ \mathrm{n}-, 6 \mathrm{~m}-/ \mathrm{n}+, 84 \mathrm{~m}-/ \mathrm{n}-)$. Similarly, IA levels of mothers and neonates correlated highly ( $r=0.75$, $p<0.0001$; Fig. 2a). Mean IA levels of mothers were $434 \pm 51[\mathrm{SEM}] \mathrm{nU} / \mathrm{ml}($ median $193 \mathrm{nU} / \mathrm{ml})$ and of neonates $476 \pm 58 \mathrm{nU} / \mathrm{ml}$ (median $198 \mathrm{nU} / \mathrm{ml}$ ). The duration of diabetes of ICA positive mothers was significantly shorter than of mothers with negative ICA (ICA + vs ICA-: $9.9 \pm 1.2[\mathrm{SEM}]$ years vs $13.4 \pm 0.8$ years; $p<0.02)$.

Of mothers with GDM, $11 \%$ (6 of 55 ) were ICA + and $18 \%(10$ of 55$) \mathrm{IA}+(>49 \mathrm{nU} / \mathrm{ml})$. Of their neonates $13 \%$ (7 of 55) were ICA + and 55\% (30 of 55) had IA above $49 \mathrm{nU} / \mathrm{ml}$ (Fig. 1b, left panel). ICA were also mainly detected in those infants whose mothers were ICA positive $(5 \mathrm{~m}+/ \mathrm{n}+, 1 \mathrm{~m}+/ \mathrm{n}-,, 2 \mathrm{~m}-/ \mathrm{n}+, 47 \mathrm{~m}-/ \mathrm{n}-)$. Although a positive correlation of I[A]A was also found in GDM (GDM-BG: $r=0.81, p<0.0001$; GDM-A: $r=0.21$, $p<0.05$; Fig. 2 b, c), some children had clearly higher titre than their mothers (i.e. three offspring of GDM-A mothers with titre of 198, 284 and $392 \mathrm{nU} / \mathrm{ml}$, respectively). Mean IAA levels of GDM-A mothers were $20 \pm 3 \mathrm{nU} / \mathrm{ml}$ and of their neonates $72 \pm 15 \mathrm{nU} / \mathrm{ml}$ $(p<0.005)$ and mean IA levels of GDM-BG mothers were $78 \pm 24 \mathrm{nU} / \mathrm{ml}$ and of their neonates $132 \pm 37 \mathrm{nU} / \mathrm{ml}$ $(p<0.02)$.

Control neonates: The normal range of cord blood IAA levels in normal neonates from healthy parents (although all were negative for ICA) was found to be higher than in normal children and adults during later life (cord blood $[n=17]: 85 \pm 19 \mathrm{nU} / \mathrm{ml}$; range 9 to $161 \mathrm{nU} / \mathrm{ml} ; 12$ of 17 above $49 \mathrm{nU} / \mathrm{ml})$. Therefore, IAA levels of neonates of non-insulin-treated GDM-A mothers were not increased compared with IAA levels of neonates of normal parents.

\section{Nine-months follow-up}

To date, 90 mother-child-pairs (66 with Type 1 and 24 with GDM) have been re-tested at 9 months postpartum. On follow-up, antibody-positivity of diabetic mothers was not 
Table 1. Antibody-positive mother-child pairs

\begin{tabular}{|c|c|c|c|c|c|c|c|c|c|c|c|c|c|c|}
\hline \multirow{3}{*}{ Subjects } & \multirow{3}{*}{$\begin{array}{l}\text { White } \\
\text { class }\end{array}$} & \multirow{3}{*}{$\begin{array}{l}\text { Birth } \\
\text { (year) }\end{array}$} & & & \multicolumn{10}{|c|}{ Follow-up postpartum } \\
\hline & & & \multicolumn{2}{|l|}{ at birth } & \multicolumn{2}{|l|}{ 9-months } & \multicolumn{2}{|l|}{ 2-years } & \multicolumn{2}{|l|}{ 2.5-years } & \multicolumn{2}{|l|}{ 3-years } & \multicolumn{2}{|l|}{ 3.5-years } \\
\hline & & & $\begin{array}{l}\text { ICA } \\
(\mathrm{JDF}-\mathrm{U})\end{array}$ & $\begin{array}{l}\mathrm{I}[\mathrm{A}] \mathrm{A} \\
(\mathrm{nU} / \mathrm{ml})\end{array}$ & $\begin{array}{l}\text { ICA } \\
\text { (JDF-U) }\end{array}$ & $\begin{array}{l}\mathrm{I}[\mathrm{A}] \mathrm{A} \\
(\mathrm{nU} / \mathrm{ml})\end{array}$ & $\begin{array}{l}\text { ICA } \\
\text { (JDF-U) }\end{array}$ & $\begin{array}{l}\mathrm{I}[\mathrm{A}] \mathrm{A} \\
(\mathrm{nU} / \mathrm{ml})\end{array}$ & $\begin{array}{l}\text { ICA } \\
(\mathrm{JDF}-\mathrm{U})\end{array}$ & $\begin{array}{l}\text { IAA } \\
(\mathrm{nU} / \mathrm{ml})\end{array}$ & $\begin{array}{l}\text { ICA } \\
(\mathrm{JDF}-\mathrm{U})\end{array}$ & $\begin{array}{l}\text { IAA } \\
(\mathrm{nU} / \mathrm{ml})\end{array}$ & $\begin{array}{l}\text { ICA } \\
\text { (JDF-U) }\end{array}$ & $\begin{array}{l}\text { LAA } \\
(\mathrm{nU} / \mathrm{ml})\end{array}$ \\
\hline Mother S.P.A. & $\mathrm{D}$ & 1954 & 80 & 68 & $<20$ & 26 & $<20$ & 7 & - & & - & - & & \\
\hline Child S.P.K. & & 1989 & 80 & 31 & $<20$ & 4 & $<20$ & 96 & - & - & 80 & 315 & & \\
\hline Mother B. A. & $\mathrm{B}$ & 1952 & 20 & 1741 & $<20$ & 302 & $<20$ & 1771 & - & - & & & & \\
\hline Child B.B.2 & & 1990 & $<20$ & 1815 & $<20$ & 159 & $<20$ & 1174 & 160 & 1451 & & & & \\
\hline Child B.B. 1 & & 1988 & - & - & - & - & - & - & 80 & 468 & 160 & 856 & 160 & $1278^{\mathrm{b}}$ \\
\hline Mother S.K. & A & 1946 & $<20$ & 18 & $<20$ & 13 & $<20$ & 18 & & & & & & \\
\hline Child S. T. & & 1990 & $<20$ & 48 & $<20$ & 89 & 40 & 182 & & & & & & \\
\hline Mother M.S. & $\mathrm{C}$ & 1966 & $<20$ & 16 & $<20$ & 25 & $<20$ & 33 & & & & & & \\
\hline Child M.N. ${ }^{a}$ & & 1990 & $<20$ & 8 & $<20$ & $167^{\mathrm{a}}$ & $<20$ & 23 & & & & & & \\
\hline
\end{tabular}

${ }^{a}$ transient IAA-positive; ${ }^{b}$ B. B. 1 developed type 1 diabetes at age 3.5 years.

ICA, Islet cell antibodies; I[A]A, insulin autoantibodies, normal range $\leq 49 \mathrm{nU} / \mathrm{ml}$

Table 2. Clinical features of mothers and offspring according to antibody status at 2 years of age

\begin{tabular}{|c|c|c|c|c|c|c|c|}
\hline & \multicolumn{3}{|l|}{ Mother } & \multicolumn{4}{|l|}{ Offspring } \\
\hline & $\begin{array}{l}\text { Age at } \\
\text { delivery } \\
\text { (years) }\end{array}$ & $\begin{array}{l}\text { Diabetes } \\
\text { duration } \\
\text { (years) }\end{array}$ & $\begin{array}{l}\text { Mean } \\
\mathrm{Hb} A_{1} \\
(\%)\end{array}$ & $\begin{array}{l}\text { Gestation } \\
\text { (week) }\end{array}$ & $\begin{array}{l}\text { Cord blood } \\
\text { insulin } \\
(\mu \mathrm{U} / \mathrm{ml})\end{array}$ & $\begin{array}{l}\text { Breast } \\
\text { feeding } \\
\text { (months) }\end{array}$ & $\begin{array}{l}\text { Birth } \\
\text { weight } \\
\text { (g) }\end{array}$ \\
\hline Range & $19-36$ & $0.5-24$ & $5.6-8.3$ & $24-41$ & 3-155 & $0-7$ & $2077-5100$ \\
\hline Median & $28^{a}$ & 11 & 6.7 & 39 & 14.5 & 2 & 3430 \\
\hline \multicolumn{8}{|c|}{ Antibody-positive $(n=3)$} \\
\hline B.B.2 & 38 & 3 & 7.8 & 38 & 53 & 1 & 3050 \\
\hline S.P.K. & 35 & 17 & 5.4 & 42 & 63 & 0.5 & 3640 \\
\hline S.T. & 44 & $0[\mathrm{GDM}]$ & 6.1 & 41 & 8 & 0 & 3950 \\
\hline Median & $38^{a}$ & 3 & 6.1 & 41 & 53 & 0.5 & 3640 \\
\hline
\end{tabular}

${ }^{\mathrm{a}} p<0.001$.

25-75 P,25th to 75th percentile; GDM, gestational diabetes

significantly different from birth: of Type 1 diabetic mothers $18 \%$ (12 of 66) were positive for ICA and $85 \%$ (56 of 66 ) for IA and of GDM mothers $4 \%$ ( 1 of 24$)$ were positive for ICA and $4 \%$ ( 1 of 24 ) for I[A]A (Fig. 1 a, b, middle panel). In contrast, the majority of children had lost their antibody-positivity during their first 9 months of life, except for three infants (total: 3 of $90=3.3 \%$; of mothers with Type 1: 2 of $66=3 \%$; of mothers with GDM: 1 of $24=4 \%$ ), who were found to be IAA + at 9 months of age (IAA-level: patient B.B.2 $159 \mathrm{nU} / \mathrm{ml}$, patient M.N. $167 \mathrm{nU} / \mathrm{ml}$, patient S. T. $89 \mathrm{nU} / \mathrm{ml}$; Table 1$)$. None $(0$ of 90$)$ of the infants, however, had positive ICA ( $\geq 20$ JDF-U) at this age.

\section{Two-years follow-up}

To date, 39 mother-child-pairs ( 28 with Type 1 and 11 with GDM) have been re-tested 2 years postpartum. Antibody-positivity of Type 1 diabetic mothers was $14 \%$ (4 of 28 ) for ICA and $68 \%$ (19 of 28 ) for IA and for mothers with GDM, $0 \%$ for ICA and $27 \%$ (3 of 11 ) for I[A]A (Fig. 1 a,b, right panel). At 2 years of age, the majority of children remained antibody-negative, except three infants (total: 3 of $39=7.7 \%$; of mothers with Type 1: 2 of
$28=7 \%$; of mothers with GDM: 1 of $11=9 \%$ ) who were identified as having elevated antibody-titre: two infants were IAA +/ICA- (patient B.B.2: IAA $1174 \mathrm{nU} / \mathrm{ml}$; patient S.P.K.: IAA $96 \mathrm{nU} / \mathrm{ml}$ ) and one infant was IAA + /ICA + (patient S.T: IAA $182 \mathrm{nU} / \mathrm{ml}$ and ICA 40 JDF-U) (Table 1, Fig. 1 a,b). This implies, that since the 9-month follow-up patient B.B.2 remained IAA positive, patient S. T. remained IAA positive and converted to ICA positivity, patient S.P.K. was antibody-negative before and converted to IAA positive, and patient M.N. had lost IAA positivity (Table 1).

Follow-up samples of child B.B..$_{2}$ and child S.P.K. were obtained recently at age 2.5 and 3.0 years, respectively. Both infants were consistently positive for IAA with increasing titre (IAA: B. B. $1278 \mathrm{nU} / \mathrm{ml}$; S.P.K. $315 \mathrm{nU} / \mathrm{ml}$ ) and both infants had converted to ICA-positivity at 2.5 years and 3.0 years of age, respectively (ICA: B.B.2 160 JDF-U; S.P.K. 80 JDF-U) (Table 1 ).

\section{Control children}

None of 20 control children less than 2 years of age were ICA positive nor exceeded our upper limit of normal range for IAA ( $49 \mathrm{nU} / \mathrm{ml})$ defined mainly with adult con- 

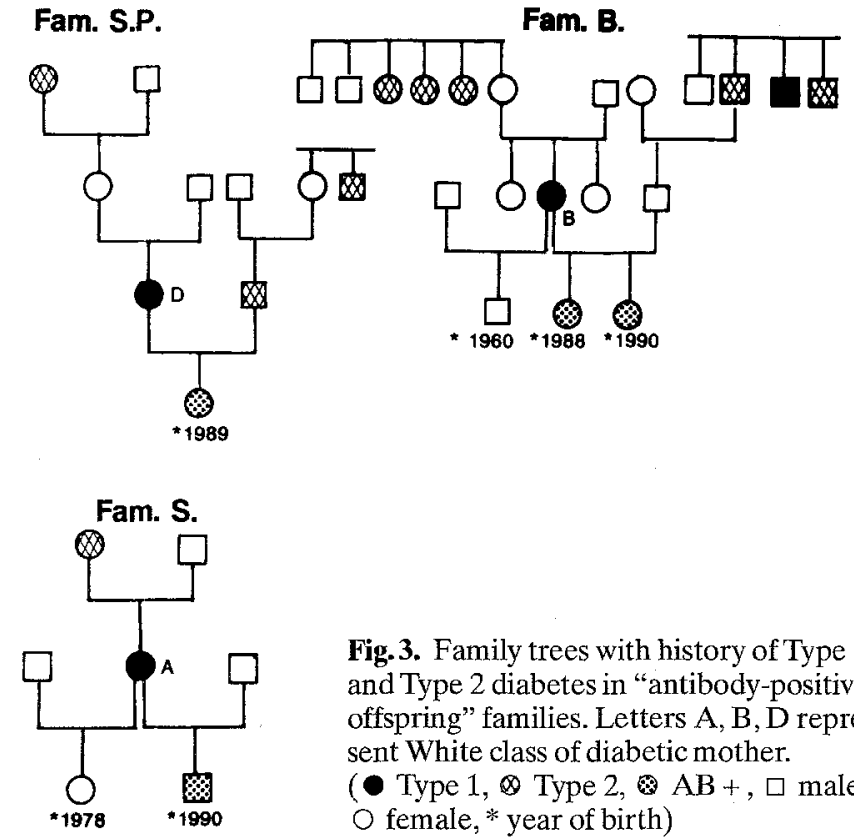

Fig.3. Family trees with history of Type 1 and Type 2 diabetes in "antibody-positive offspring" families. Letters A, B, D represent White class of diabetic mother.

(๑ Type 1, Type 2, $\mathrm{AB}+, \square$ male, $O$ female, * year of birth)

trol subjects (IAA in normal children $<2$ years of age: range -4 to $34 \mathrm{nU} / \mathrm{ml}$ ). In addition, none of 14 additional control subjects less than 5 years of age, who were studied by the same IAA assay in a previous investigation, were positive for the presence of IAA (range-44.9 to $29.3 \mathrm{nU} / \mathrm{ml}$ ) [15].

\section{Siblings of "neonates"}

In addition, all existing siblings $(n=18)$ of the neonates of this study were also investigated for ICA and IAA. One of $18(5.6 \%)$ siblings was detected as being positive for IAA and ICA (patient B.B. ${ }_{1}$ : 2.5 years of age at initial test, IAA $468 \mathrm{nU} / \mathrm{ml}$, ICA $80 \mathrm{JDF}-\mathrm{U}$ ). Patient B.B. ${ }_{.1}$ is the sister of patient B. B.2 $($ IAA + ) (see follow-up at 3 years and 3.5 years of age, Table 1 ). Patient B.B.1 developed overt Type 1 diabetes at age 3.5 years, diagnosed with an oral glucose tolerance test ( 2 -h post prandial blood glucose: $15.6 \mathrm{mmol} / \mathrm{l})$.

\section{Clinical characteristics and family history in antibody positive and antibody negative offspring at 2 years of age}

Table 2 demonstrates median and mean values and range and 25 th to 75 th percentiles of maternal and fetal variables according to antibody-positivity $(\mathrm{AB}+)$ or antibody-negativity $(\mathrm{AB}-)$ of the offspring. The maternal age at delivery was significantly higher in mothers with $\mathrm{AB}+$ than with $\mathrm{AB}$ - offspring (median 38 years vs 28 years, $p<0.0001$ ). No apparent association was noted between the presence of ICA and IAA in offspring of diabetic mothers or any other variables including maternal class of diabetes, maternal diabetes duration, maternal mean $\mathrm{HbA}_{1}$, fetal gestation age, cord blood insulin levels, breast feeding, and fetal growth for this small cohort.
Figure 3 and Table 3 present the history of Type 1 and Type 2 diabetes in families with $\mathrm{AB}+$ compared to $\mathrm{AB}-$ offspring. The frequency of Type 2 diabetes in second degree relatives of $\mathrm{AB}+$ offspring was surprisingly high on the mother's $(100 \%)$ and on the father's side $(67 \%)$. In addition, the father of offspring S.P. was identified as a Type 2 diabetic patient. The incidence of Type 2 diabetes in 2nd degree relatives of AB-offspring was lower ( $48 \%$ on the mother's side and $16 \%$ on the father's side), but the difference did not reach statistical significance.

\section{Discussion}

For the first time, a prospective study from birth for the determination of IAA and ICA was performed in offspring of mothers with Type 1 diabetes and gestational diabetes. The most striking result was that antibodies to islet cell products were detected very early in life.

At birth, a strong correlation between the presence of ICA and IA in the cord blood and in maternal circulation was observed. These results confirm previous findings from different groups who demonstrated positive ICA and IA in a significant proportion of neonates at birth [1618]. It has been suggested that ICA and IA are transplacentally acquired since antibody activity was mainly observed in those infants whose mothers were also antibody-positive at the time of delivery. For the present study, however, it is noteworthy, that although levels of insulin antibodies were similar in neonates and in insulintreated mothers, fetal IAA levels did not well reflect those of non-insulin-treated diabetic mothers.

On the other hand, new evidence was also obtained that the normal range of cord blood IAA from infants of healthy parents seems to be higher than the normal range of IAA levels obtained very shortly later in life. This might be in accordance with the elevation of other blood parameters examined in cord blood samples of normal neonates which are known to return to normal values within few weeks after birth [19].

During follow-up, the majority of children, who were antibody-positive at birth, lost their antibody-positivity within the first 9 months of life. The primary finding, however, was, that three offspring were identified as being antibody-positive at follow-up. They were all consistently

Table 3. Family history of Type 1 and Type 2 diabetes according to antibody status at 2 years of age

\begin{tabular}{lcc}
\hline & $\begin{array}{l}\text { Antibody-positive } \\
\text { offspring } \\
n=3\end{array}$ & $\begin{array}{l}\text { Antibody-negative } \\
\text { offspring } \\
n=36\end{array}$ \\
\hline $\begin{array}{l}\text { Type 1 } \\
\text { Father }\end{array}$ & $0 \%$ & $0 \%$ \\
2nd degree relatives & $0 \%$ & $10 \%$ \\
Mother's side & $33 \%$ & $6 \%$ \\
Father's side & $33 \%$ & $0 \%$ \\
$\begin{array}{l}\text { Type 2 } \\
\text { Father }\end{array}$ & $100 \%$ & $48 \%$ \\
2nd degree relatives & & $16 \%$ \\
Mother's side & $67 \%$ & \\
Father's side & & \\
\hline
\end{tabular}


positive for IAA and ICA, once they had acquired elevated antibody-titre and all three offspring developed IAA before they developed positive ICA of more than 20 JDF-U.

It has been reported by Warram and colleagues that offspring of women with Type 1 diabetes have a lower risk of developing Type 1 diabetes than offspring of men with Type 1 diabetes [4]. By age 20 years, $6.1 \%$ of offspring of diabetic fathers, but only $1.3 \%$ of offspring of diabetic mothers had the disease [4]. Similarly, the risk of children who were in utero when Type 1 diabetes developed in their mothers was described as being low [20]. With respect to these data, the prevalence of $7.7 \%$ positivity of IAA and ICA in offspring of diabetic mothers at 2 years of age is remarkably high in the present study. In addition, one further sibling of the prospectively followed antibody-positive neonates was also detected as being persistently IAA + /ICA + from the age of 2.5 years and older and was diagnosed as having overt Type 1 diabetes at 3.5 years. Similarly, one has to assume that the other three $\mathrm{IAA}+/ \mathrm{ICA}+$ offspring are at very high risk of developing diabetes. The experience from previous studies with antibody screening of first degree relatives of Type 1 diabetic patients clearly demonstrated - by life table analysis - that individuals who are positive for both ICA and IAA (and especially those who have IAA levels above $150 \mathrm{nU} / \mathrm{ml}$ ) have the highest rate of progression to overt diabetes ( $100 \%$ within five years [9]). These high risk criteria were fulfilled in all our positive offspring at the most recent follow-up.

There may be several explanations for the high prevalence of antibody-positivity in the offspring of our cohort: 1) the incidence of Type 1 diabetes is rising in offspring of diabetic mothers; 2 ) the incidence is different in the population we studied; 3 ) the high prevalence of ICA and IAA is an artefact through the relatively small number of offspring followed up to 2 years of age. On the other hand, the figure found in our study might even be an underestimate and there will be additional children who become antibody-positive later in life.

In the present investigation, antibody-positivity in offspring of diabetic mothers was significantly correlated with older maternal age at delivery. This is in contrast to findings by Warram and coworkers [21], who reported that offspring born at maternal age above 25 years had a significantly lower risk than those born at younger maternal ages, whereas Bleich and coworkers [22] described a higher risk for offspring of diabetic mothers with long duration of diabetes, especially when the mother acquired diabetes before age 12 . The present study neither indicated a correlation between the presence of antibodies and maternal diabetes duration nor age of maternal diabetes onset. In addition, no apparent association was noted between the presence of ICA and IAA in offspring of diabetic mothers and any other clinical variables including maternal class of diabetes, maternal mean $\mathrm{HbA}_{1}$, fetal gestational age, cord blood insulin levels, fetal growth, and breast feeding (some associations, however, may become significant, when larger numbers of offspring are studied). It was reported that exclusive breast feeding with delayed exposure to infant formula diet based on cow's milk significantly reduced the risk of diabetes $[23,24]$. In this context, the time of breast feeding was remarkably low in the ICA +/IAA + offspring (median 0.5 months) of the present study, yet not significantly different compared with the antibody-negative group (me$\operatorname{dian} 2$ months).

The frequency of Type 2 diabetes in second degree relatives was high in ICA +/IAA + infants compared to antibody-negative infants, but the difference did not reach statistical significance. This observation might be in line with our previous survey, in which a striking frequency of Type 2 diabetes among second degree relatives of Type 1 diabetic patients was demonstrated $(47 \%$ of Type 1 families vs $19 \%$ of control families were found to have second degree relatives with Type 2 diabetes, $p=0.0003$ ), although it has been suggested that Type 1 and Type 2 diabetes are two distinct entities based on a different genetic background [25].

In summary we conclude that insulin autoantibodies and islet cell antibodies are acquired at very young age in offspring of mothers with Type 1 diabetes and gestational diabetes. Antibody screening at the age of 2 years might be a very useful tool to detect individuals at high-risk for the development of childhood Type 1 diabetes.

Acknowledgements. We gratefully acknowledge the assistance of Dr. K. Brauch (3rd Medical Department, Schwabing City Hospital) and all nurses of the delivery room (Department of Obstetrics and Gynaecology, Schwabing City Hospital). This work was supported by a grant from the German Diabetes Association.

\section{References}

1. Ziegler AG, Eisenbarth GS (1990) Immunology of diabetes. In: Alberti KGMM, Krall LP (eds) The diabetes annual/5. Elsevier Science, Amsterdam, pp 22-50

2. Warram JH, Krolewski AS, Gottlieb MS, Kahn CR (1984) Differences in risk of insulin-dependent diabetes in offspring of diabetic mothers and diabetic fathers. N Engl J Med 311:149-152

3. Tillil H, Koebberling J (1987) Age-corrected empirical genetic risk estimates for first-degree relative of IDDM patients. Diabetes 36: 93-99

4. Warram JH, Krolewski AS, Kahn CR (1988) Determinants of IDDM and perinatal mortality in children of diabetic mothers. Diabetes 37: 1328-1334

5. Bottazzo GF, Gorsuch AN, Dean BM, Cudworth AG, Doniach D (1980) Complement-fixing islet cell antibodies in type 1 diabetes: possible monitors of active beta cell damage. Lancet I: $668-672$

6. Palmer JP, Asplin CM, Clemons P et al. (1983) Insulin antibodies in insulin dependent diabetes before insulin treatment. Science 222: $1337-1339$

7. Atkinson MA, Maclaren NK, Riley WJ, Winter WE, Fisk DD, Spillar RP (1986) Are insulin autoantibodies markers for insulin dependent diabetes mellitus? Diabetes 35: 894-898

8. Tarn AC, Thomas JM, Dean BM et al. (1988) Predicting insulin dependent diabetes. Lancet I: $845-850$

9. Ziegler AG, Ziegler R, Vardi P, Jackson RA, Soeldner JS, Eisenbarth GS (1989) Life table analysis of progression to diabetes of anti-insulin autoantibody positive relatives of type 1 diabetics. Diabetes 38: 1320-1325

10. Ziegler AG, Herskowitz R, Jackson RA, Soeldner JS, Eisenbarth GS (1990) Predicting type 1 diabetes. Diabetes Care 13: $762-775$

11. Vardi P, Dib SA, Tuttleman M et al. (1987) Competitive insulin autoantibody RIA: prospective evaluation of subjects at high 
risk for development of type I diabetes mellitus. Diabetes 36 : $1286-1291$

12. Ziegler AG, Rabl W, Albert E, Standl E (1991) Insulin-Autoantikörper und Inselzell-Antikörper in Abhängigkeit vom Manifestationsalter und HLA-Phänotyp bei Patienten mit neumanifestem Typ-I-Diabetes mellitus. Dtsch med Wschr 116: $1737-1741$

13. Srikanta S, Rabizadeh A, Omar MAK, Eisenbarth GS (1985) Assay for islet cell antibodies: protein A monoclonal antibody method. Diabetes 34:300-305

14. Soeldner JS, Srikanta S, Eisenbarth GS, Gleason RE (1986) Prehyperglycemic diabetes mellitus. Clin Chem 32: B7-B18

15. Vardi P, Ziegler AG, Mathews JH et al. (1988) Concentrations of insulin autoantibodies at onset of type 1 diabetes: inverse loglinear correlation with age. Diabetes Care 11: 736-739

16. Tingle AJ, Lim G, Wright VJ, Dimmick JE, Hunt JA (1979) Transplacental passage of islet cell antibody in infants of diabetic mothers. Pediat Res 13: 1323-1325

17. Leiper JM, Fineberg SE, Lunan CB, MacCuich AC (1984) Insulin antibodies in the maternal and foetal circulation of pregnant diabetic women treated with human insulin of recombinant DNA origin. Diabetes Res 1: 75-81

18. Di Mario U, Falluca F, Gargiulo P et al. (1984) Insulin-anti-insulin complexes in diabetic women and their neonates. Diabetologia 27: 83-86

19. Bidlingmaier F, Witt I (1977) Normalwerte im Blut. In: Keller, Wiskott (eds) Lehrbuch der Kinderheilkunde. Georg Thieme Verlag, Stuttgart, pp 2-6

20. Buschard K, Kühl C, Molsted-Pedersen L, Lund E, Palmer J, Bottazzo GF (1989) Investigations in children who were in utero at onset of insulin-dependent diabetes in their mothers. Lancet 1: $811-814$

21. Warram JH, Martin BC, Krolewski AS (1991) Risk of IDDM in children of diabetic mothers decreased with increasing maternal age at pregnancy. Diabetes 40: 1679-1684

22. Bleich D, Polak M, Eisenbarth GS, Jackson RA (1991) Increased risk of type 1 diabetes and diabetes related autoantibodies in siblings of families with two type 1 diabetic members. Diabetes 40: 143 A (Abstract)

23. Mayer EJ, Hamman RH, Gay EC et al. (1988) Reduced risk of IDDM among breast-fed children. The Colorado IDDM registry. Diabetes 37: 1625-1632

24. Karjalainen J, Martin JM, Knip Met al. (1992) A bovine albumin peptide as a possible trigger of insulin-dependent diabetes mellitus. N Engl J Med 327: 302--307

25. Ziegler AG, Baumgartl HJ, Mühlbauer K, Mehnert S, StandI E (1992) Family history for diabetes of type 1 diabetics: evidence for a common predisposition for type 1 and type 2 diabetes. Diabetes und Stoffwechsel 1: 14-17

Received: 28 September 1992

and in revised form: 27 November 1992

Dr. A.-G.Ziegler

Diabetes Research Institute

Schwabing City Hospital

Koelner Platz 1

W-8000 Munich 40

Germany 